\title{
Comparison of methods to isolate DNA from Caesalpinia ferrea
}

\author{
C.C. Sousa' ${ }^{1}$, S.O. Gomes ${ }^{2}$, A.C.A. Lopes ${ }^{3}$, R.L.F. Gomes ${ }^{2}$, F.B. Britto ${ }^{3}$, \\ P.S.C. Lima ${ }^{4}$ and S.E.S. Valente ${ }^{3}$
}

${ }^{1}$ Departamento de Ciências Naturais, Universidade Federal do Maranhão, Campus Grajaú, Grajaú, MA, Brasil

${ }^{2}$ Departamento de Agronomia, Universidade Federal do Piauí, Campus Ininga, Teresina, PI, Brasil

${ }^{3}$ Departamento de Biologia, Universidade Federal do Piauí, Campus Ininga, Teresina, PI, Brasil

${ }^{4}$ Empresa Brasileira de Pesquisa Agropecuária, EMBRAPA Meio-Norte, Teresina, PI, Brasil

Corresponding author: C.C. Sousa

E-mail: camilacampelobr@hotmail.com

Genet. Mol. Res. 13 (2): 4486-4493 (2014)

Received September 26, 2013

Accepted March 7, 2014

Published June 16, 2014

DOI http://dx.doi.org/10.4238/2014.June.16.7

\begin{abstract}
Molecular markers are important for characterizing the genetic diversity of plants and can provide the basis for strategies to protect and conserve endangered populations. However, numerous molecular techniques are used, requiring an evaluation of fast and efficient methods to extract DNA. Since molecular studies of Caesalpinia ferrea are rare, it is important to develop and/or adapt a DNA extraction protocol that produces quality DNA samples to enable the design of strategies for the conservation of this threatened species. This study aimed to compare five methods for DNA extraction and to determine the most efficient protocol for $C$. ferrea. Sufficient genomic DNA was obtained from the leaves of $C$. ferrea using all the tested protocols to perform techniques
\end{abstract}


involving molecular markers. Two protocols based on the detergent cetyl trimethyl ammonium bromide, as well as a commercial kit, yielded high concentrations of pure DNA. However, when polymerase chain reaction amplifications were performed, DNA was only successfully amplified from extractions performed with the commercial kit, which produced sufficient genomic DNA of good quality from the leaves of $C$. ferrea to perform techniques involving molecular markers.

Key words: DNA isolation; Polymerase chain reaction; Protocol

\section{INTRODUCTION}

Caesalpinia ferrea Mart. belongs to the legume family and is an economically important species with multiple applications in construction, which utilizes its wood, and in folk medicine, where fractions of stem and fruit extracts are used to treat bronchopulmonary and gastrointestinal disorders and diabetes (Lucinda et al., 2010; Vasconcelos et al., 2011). Nakamura et al. (2002) and Pereira et al. (2012) reported the antitumor and anti-inflammatory properties of its fruit, which is an excellent source of energy with a large carbohydrate content that is used to feed ruminants. Nozaki et al. (2007) demonstrated that C. ferrea inhibited human topoisomerase II and induced apoptosis in HL60 human leukemia cells, suggesting that this species has potential as an anti-cancer agent.

In semi-arid regions, C. ferrea is important in the marginal vegetation of watercourses, controlling erosion, siltation, and temperature, as well as serving as a windbreak (Santos et al., 2010). Moreover, this tree is popular as fodder for cattle in extensive rearing conditions. However, it is exploited because its wood is hard and heavy; therefore, it is utilized to manufacture beams, piles, and foundations. For this reason, the population of this tree species has been devastated in northeast Brazil and is currently an endangered tree. Therefore, molecular studies are necessary to characterize the genetic diversity of this species and to assist the collection and conservation programs for $C$. ferrea trees.

For conservation management to be performed using molecular techniques, a sufficient concentration of quality DNA is required for amplification reactions, digestions, and cloning (Nunes et al., 2011), as well as for further characterization and genetic diversity analyses. These studies typically involve numerous researchers and samples, necessitating an inexpensive and rapid method for DNA extraction. For this reason, various protocols have been developed and adapted for each situation because there is significant variability in the biochemical composition of plants and tissues.

This study aimed to evaluate four protocols based on cetyltrimethylammonium bromide (CTAB) and a commercial purification kit (Invisorb Spin Plant Mini Kit, Invitek, Berlin, Germany) for DNA extraction from samples of young $C$. ferrea leaves based on the yield of a high concentration of pure DNA.

\section{MATERIAL AND METHODS}

\section{Biological material and study location}

This study was performed at the Laboratory of Molecular Biology, Department of Soil 
Science, Universidade Federal do Piauí (UFPI), and the Laboratory of Molecular Biology, Empresa Brasileira de Pesquisa Agropecuária (EMBRAPA Meio-Norte).

Genomic DNA was extracted from $100 \mathrm{ng}$ young leaves. The samples were properly identified, placed in plastic bags, stored at a low temperature $\left(0^{\circ} \mathrm{C}\right)$, and transported to the Laboratory of Molecular Biology at EMBRAPA Meio-Norte, where they were placed in a freezer until the extractions were performed.

\section{DNA extraction}

Four published extraction protocols based on the detergent CTAB were tested: Doyle and Doyle (1987), Clarke et al. (1989), Ferreira and Grattapaglia (1998), and Romano and Brasileiro (1999) (reagent quantities for each extraction buffer are presented in Table 1). The commercial purification kit was also tested. The protocols were standardized to use the same amount of fresh tissue and were each performed three times.

\begin{tabular}{|c|c|c|c|c|c|c|c|}
\hline Protocol* & $\begin{array}{l}\text { CTAB } \\
(\%)\end{array}$ & $\begin{array}{l}\text { Tris-HCl } \\
(\mathrm{mM})\end{array}$ & $\begin{array}{l}\text { EDTA } \\
(\mathrm{mM})\end{array}$ & $\begin{array}{c}\beta \text {-mercaptoethanol } \\
(\%)\end{array}$ & $\begin{array}{l}\text { PVP } \\
(\%)\end{array}$ & $\begin{array}{l}\mathrm{NaCl} \\
(\mathrm{M})\end{array}$ & $\begin{array}{c}\text { Time } \\
\text { (minutes) }\end{array}$ \\
\hline Doyle and Doyle (1987) & 2 & 100 & 20 & 0.2 & & 1.4 & 70 \\
\hline Clarke et al. (1989) & 2 & 100 & 150 & 0.2 & 2 & 2.1 & 200 \\
\hline Ferreira and Grattapaglia (1998) & 2 & 100 & 20 & 0.2 & 1 & 1.4 & 210 \\
\hline Romano and Brasileiro (1998) & 2 & 10 & 10 & 1 & & 1.4 & 80 \\
\hline
\end{tabular}

*Isopropanol, ethanol, chloroform, and isoamyl alcohol are not included.

For the Doyle and Doyle (1987) protocol, $175 \mu \mathrm{L}$ extraction buffer was added to the samples, which were then placed in a $65^{\circ} \mathrm{C}$ water bath for $30 \mathrm{~min}$. Subsequently, $175 \mu \mathrm{L}$ chloroform:isoamyl alcohol was added. The Eppendorf (Germany) tubes were centrifuged for $10 \mathrm{~min}$. The upper aqueous phase was collected and transferred to a new tube, and $175 \mu \mathrm{L}$ cold isopropanol was added. The precipitate was washed with $100 \mu \mathrm{L}$ ethanol, which was discarded, and the DNA was resuspended in $30 \mu \mathrm{L}$ Tris-ethylenediaminetetraacetic acid (EDTA; TE) buffer and stored at $-20^{\circ} \mathrm{C}$.

In the Clarke et al. (1989) protocol, $266 \mu \mathrm{L}$ buffer was aliquoted into each Eppendorf tube and placed in a $65^{\circ} \mathrm{C}$ water bath for $40 \mathrm{~min}$. After cooling the samples, deproteinization was performed by adding $266 \mu \mathrm{L}$ chloroform:isoamyl alcohol and centrifuging for $10 \mathrm{~min}$. The supernatant was transferred to another tube, and $20 \mu \mathrm{L} \mathrm{NaCl}$ and $266 \mu \mathrm{L}$ frozen absolute ethanol were added. The tubes were incubated at $-20^{\circ} \mathrm{C}$ for $20 \mathrm{~min}$ and then centrifuged for 5 min. The ethanol was discarded, and the pellet was placed at room temperature and resuspended in $30 \mu \mathrm{L} \mathrm{TE}$, pH 8.0.

The Ferreira and Grattapaglia (1998) protocol utilized $186.66 \mu \mathrm{L}$ buffer for each extraction. The samples were placed in a water bath for $30 \mathrm{~min}$, and then $160 \mu \mathrm{L}$ chloroform:isoamyl alcohol (24:1) was added. The Eppendorf tubes were centrifuged for $10 \mathrm{~min}$, and the upper layer was transferred to a new tube. A $1 / 10$ volume of a $10 \% \mathrm{CTAB}$ and $1.4 \mathrm{M} \mathrm{NaCl}$ mixture was added to the aqueous phase. The procedure was repeated with $160 \mu \mathrm{L}$ of chloroform:isoamyl alcohol (24:1). A 2/3 volume of isopropanol solution was added, and the tubes were incubated at $-20^{\circ} \mathrm{C}$ for $30 \mathrm{~min}$. The samples were centrifuged for $3 \mathrm{~min}$, and the pellet was washed twice 
in $248 \mu \mathrm{L} 70 \%$ ethanol. The ethanol was removed, and the sample was dried for $2 \mathrm{~h}$. The pellet was resuspended in $10 \mu \mathrm{L} \mathrm{TE}$ and stored at $-20^{\circ} \mathrm{C}$.

For the Romano and Brasileiro (1999) protocol, $200 \mu \mathrm{L}$ extraction buffer was added to each sample, and the samples were incubated in a $60^{\circ} \mathrm{C}$ water bath for $30 \mathrm{~min}$. Subsequently, $200 \mu \mathrm{L}$ chloroform:isoamyl alcohol (24:1) was added. The samples were centrifuged for 10 min to separate the organic phase from the aqueous solution. The upper aqueous phase was transferred to new tubes, and the chloroform:isoamyl alcohol (24:1) extraction was repeated two more times. A $3 / 5$ volume of isopropanol $\left(\right.$ at $\left.-20^{\circ} \mathrm{C}\right)$ was added to the samples. The supernatant was discarded, and the precipitate was washed with $66 \mu \mathrm{L} 70 \%$ ethanol. The excess moisture was removed, and the precipitate was dissolved in $30 \mu \mathrm{L}$ TE buffer $(10 \mathrm{mM}$ Tris$\mathrm{HCl}, \mathrm{pH}$ 8.0, and $1 \mathrm{mM}$ EDTA).

The reagent concentrations used to prepare the extraction solutions and the time required for each CTAB-based DNA extraction protocol are presented in Table 1.

DNA extractions were also performed using a commercial purification kit according to manufacturer recommendations. A Precellys (France) homogenizer was utilized to macerate the samples.

\section{DNA quantification}

Extracted DNA samples were separated on a $0.8 \%$ agarose gel with $0.5 \mathrm{X}$ Tris-borateEDTA (TBE) at 80 volts for $1.5 \mathrm{~h}$. The gels were stained with GelRed ${ }^{\mathrm{TM}} 10,000 \mathrm{X}$ (Uniscience, United States) and imaged under ultraviolet light. The resolution of the DNA samples was compared with 100 ng $\lambda$-DNA.

\section{Amplification reactions}

The polymerase chain reaction (PCR) amplifications were performed in a Veriti 96Well Thermal Cycler (Applied Biosystems ${ }^{\circledR}$, United States) with an initial denaturation step of $1 \mathrm{~min}$ at $92^{\circ} \mathrm{C}$; 45 cycles of $1 \mathrm{~min}$ at $92^{\circ} \mathrm{C}$ (denaturation), 1 min at $35^{\circ} \mathrm{C}$ (primer annealing), and $2 \mathrm{~min}$ at $72^{\circ} \mathrm{C}$; and a final extension of $5 \mathrm{~min}$ at $72^{\circ} \mathrm{C}$.

The two random amplification of polymorphic DNA primers were M15 (5'-CTAGACCCAC-3') and T04 (5'-GGACTAGAGT-3'). The reactions (20 $\mu \mathrm{L}$ final volume) contained $15 \mathrm{ng}$ DNA, $0.25 \mathrm{mM}$ dNTPs, $1 \mathrm{U}$ Taq DNA polymerase (Invitrogen), $0.2 \mathrm{mM}$ primer, $3.0 \mathrm{mM} \mathrm{MgCl}_{2}, 2.0 \mu \mathrm{L} 1 \mathrm{X}$ buffer, and ultrapure $\mathrm{H}_{2} \mathrm{O}$.

The amplification products were separated on a $1.5 \%$ agarose gel with $0.5 \mathrm{X}$ TBE buffer at 80 volts for $4 \mathrm{~h}$, and the gels were stained with GelRed ${ }^{\mathrm{TM}} 10.000 \mathrm{X}$ (Uniscience). The sizes of the amplified fragments were determined based on a 1-kb DNA ladder (Invitrogen), and the products were visualized on an ultraviolet transilluminator and documented.

\section{RESULTS}

After the extractions, we observed the formation of a DNA pellet in each tube. A clear pellet is not the first indication of the presence of impurities in the samples. The pellet appeared clear when the protocols published by Doyle and Doyle (1987), Ferreira and Grattapaglia (1998), and Romano and Brasileiro (1999), as well as the commercial kit, were utilized. 
In contrast, the protocol published by Clarke et al. (1989) yielded a yellowish pellet, which is indicative of an impure sample.

The agarose gel results suggested that the DNA obtained using each protocol was not degraded, suggesting that this genetic material could feasibly be utilized in molecular studies. However, when the Romano and Brasileiro (1999), Ferreira and Grattapaglia (1998), and commercial kit protocols were employed, the extracted DNA was at a higher concentration than the $\lambda$-DNA (Figure 1).

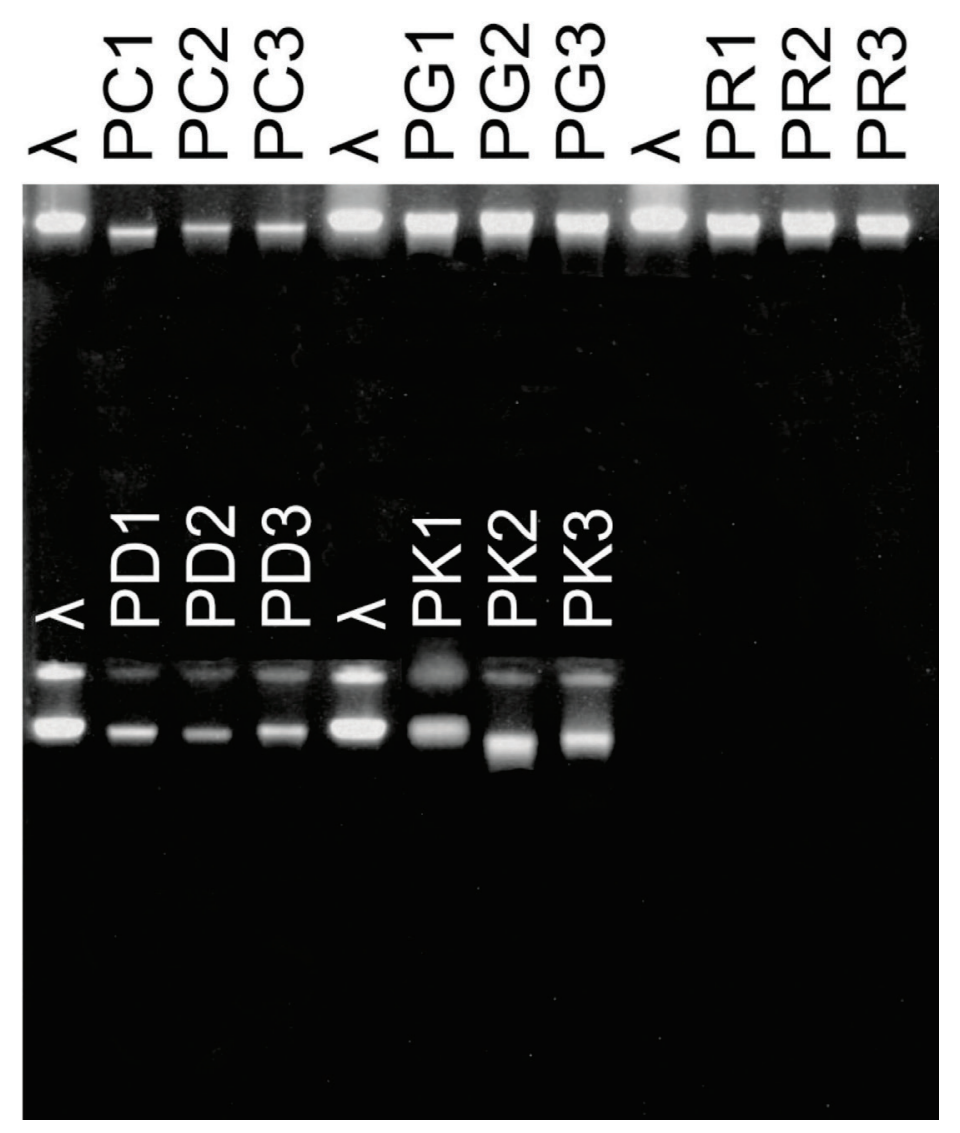

Figure 1. Agarose gel electrophoresis (0.8\%) of Caesalpinia ferrea DNA obtained from young leaves via different DNA extraction methods. There were three replicates for each protocol. Each lane contains $5 \mu \mathrm{L}$ of genomic DNA, $2 \mu \mathrm{L}$ of bromophenol blue loading buffer and $1 \mu \mathrm{L}$ of GelRed $^{\mathrm{TM}} 10.000 \mathrm{X}$ (Uniscience). $\lambda=100$-bp molecular weight marker (Invitrogen); PC = Clarke et al. protocol; PG = Ferreira and Grattapaglia protocol; PR = Romano and Brasileiro protocol; $\mathrm{PD}=$ Doyle and Doyle protocol; $\mathrm{PK}=$ commercial kit.

The amplification reactions were performed with primers that had good resolution and band patterning with DNA extracted using the commercial kit, indicating that the amount and quality of extracted DNA were sufficient to perform polymerase chain reaction (PCR). These PCR products can be utilized in molecular studies to identify strategies for species conservation (Figure 2). 


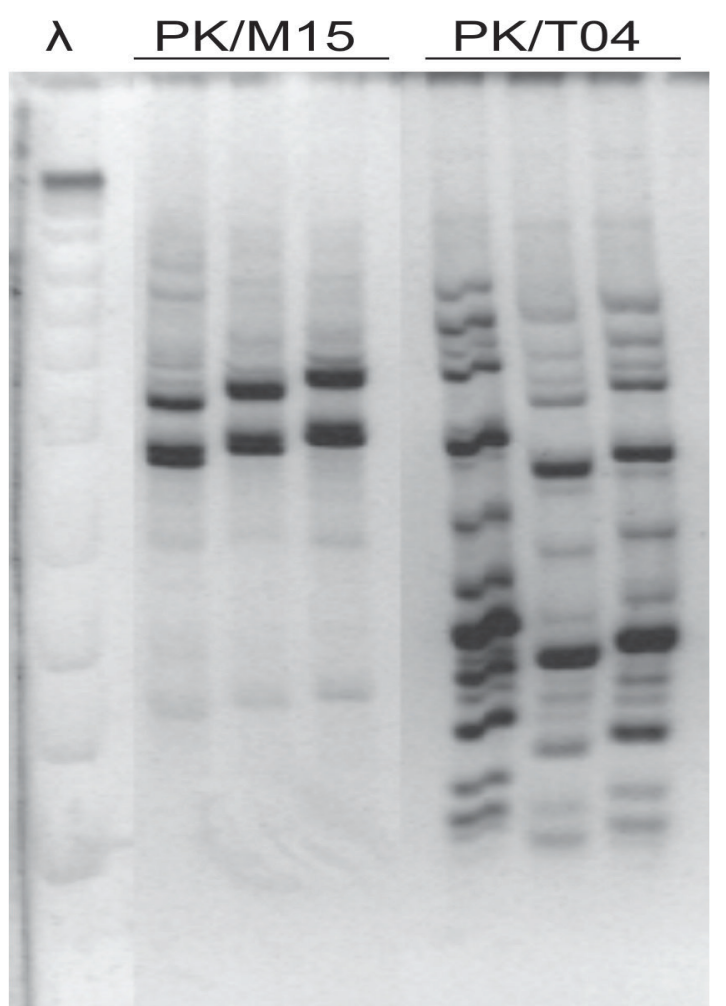

Figure 2. Amplification reactions with the RAPD primers M15 and T04 in Caesalpinia ferrea DNA samples extracted using the commercial kit. $\lambda=100$-bp molecular weight marker (Invitrogen).

\section{DISCUSSION}

Of the protocols tested, the Romano and Brasileiro (1999) protocol used the least Tris$\mathrm{HCl}$ and EDTA. Tris-HCl maintains a constant $\mathrm{pH}$ (approximately 8.0 or 9.0) to inhibit the action of endogenous nucleases that degrade DNA at an optimum $\mathrm{pH}$ of 7.0. EDTA chelates divalent cations, such as $\mathrm{Mg}^{2+}$ and $\mathrm{Ca}^{2+}$. EDTA forms a complex with these ions, thereby inhibiting DNases that utilize these metals as cofactors. Although the protocol published by Romano and Brasileiro (1999) utilized smaller reagent quantities, representing an economic use of material, this protocol required more $\beta$-mercaptoethanol (an antioxidant), which may have produced more favorable results. However, $\beta$-mercaptoethanol is neurotoxic, which highlights a disadvantage of this protocol.

The protocol published by Ferreira and Grattapaglia (1998) was the only one among the top three protocols that included polyvinylpyrrolidone (PVP) in the buffer solution. PVP has antioxidant properties and is responsible for deproteinization and the removal of polyphenols, tannins, and quinone that are present in large quantities in plants belonging to the Caesalpinioideae family. Borges et al. (2012) compared the DNA extracted from another species in the Caesalpinioideae family, Melanoxylon brauna, using the Doyle and Doyle (1987) and Ferreira and Grattapaglia (1998) protocols, and they determined that the DNA extracted using the second protocol was of a better quality and greater quantity. 
Even though the Clarke et al. (1989) protocol utilized higher concentrations of PVP and EDTA in the buffer solution and had the highest concentration of $\mathrm{NaCl}$, which contributes positive ions that neutralize the negative charge of DNA and reduces DNA contamination with polysaccharides, this extraction protocol did not have satisfactory results.

The use of a commercial kit for DNA extraction has many advantages, including practicality and simplicity, the lack of corrosive reagents (such as phenol and chloroform), the inclusion of more pure reagents, and reproducibility in terms of DNA production. However, a few studies in the literature have reported that DNA extraction using a commercial kit generated so little DNA that molecular analyses were not possible; the higher cost is also a disadvantage (Bitencourt et al., 2007).

Rapid protocols are necessary, and speed is an important prerequisite for the quality assurance of the tested materials (Gupta et al., 2012). The protocols published by Doyle and Doyle (1987) and Romano and Brasileiro (1999) had the shortest execution times (Table 1).

The protocols published by Romano and Brasileiro (1999) and Ferreira and Grattapaglia (1998), as well as the commercial kit, yielded higher concentrations of good quality DNA. However, when PCR amplifications were performed, DNA was only successfully amplified from extractions performed with the commercial kit. Based on the methodologies that were studied and the results, the commercial kit produced sufficient genomic DNA of good quality from the leaves of $C$. ferrea to perform techniques involving molecular markers.

\section{ACKNOWLEDGMENTS}

The authors thank Universidade Federal do Piauí and EMBRAPA Meio-Norte for providing laboratory facilities for this study and Conselho Nacional de Desenvolvimento Científico e Tecnológico for the support.

\section{REFERENCES}

Bitencourt JVT, Roratto PA, Bartholomei-Santos ML and Santos S (2007). Comparison of different methodologies for DNA extraction from Aegla longirostri. Braz. Arch. Biol. Technol. 50: 989-994.

Borges DB, Amorim MB, Waldschmidt AM, Mariano-Neto E, et al. (2012). Optimization of DNA extraction from fresh leaf tissues of Melanoxylon brauna (Fabaceae). Genet. Mol. Res. 11: 1586-1591.

Clarke BC, Moran LB and Appels R (1989). DNA analyses in wheat breeding. Genome 32: 334-339.

Doyle JJ and Doyle JL (1987). A rapid DNA isolation procedure for small quantities of fresh leaf tissue. Phytochem. Bull. 19: 11-15.

Ferreira ME and Grattapaglia D (1998). Introdução ao Uso de Marcadores Moleculares em Análise Genética. 3rd edn. Embrapa, Cenargen, Brasília.

Gupta R, Chandrashekar US, Chakrabarty SK and Dadlani M (2012). A simple modified method of DNA extraction from seeds for PCR amplifications. Indian. J. Agr. Sci. 82: 75-77.

Lucinda LM, Rocha CB, Reboredo MM, Faria VC, et al. (2010). Assessment of sperm production and reproductive organs of Wistar rats to long-term exposure of Caesalpinia ferrea. An. Acad. Bras. Ciênc. 82: 907-914.

Nakamura ES, Kurosaki F, Arisawa M, Mukainaka T, et al. (2002). Cancer chemopreventive effects of constituents of Caesalpinia ferrea and related compounds. Cancer Lett. 177: 119-124.

Nozaki H, Hayashi K, Kido M and Kakumoto K (2007). Pauferrol A, a novel chalcone trimer with a cyclobutane ring from Caesalpinia ferrea mart exhibiting DNA topoisomerase II inhibition and apoptosis-inducing activity. Tetrahedron Lett. 48: 8290-8292.

Nunes CF, Ferreira JL, Fernandes MCN and Breves SS (2011). An improved method for genomic DNA extraction from strawberry leaves. Ciênc. Rural 41: 1383-1389.

Pereira LP, da Silva RO, Bringel PH, da Silva KE, et al. (2012). Polysaccharide fractions of Caesalpinia ferrea pods: 
potential anti-inflammatory usage. J. Ethnopharmacol. 139: 642-648.

Romano E and Brasileiro ACM (1999). Extração de DNA de plantas. Biotecnol. Ciênc. Desenvolv. 5: 40-43.

Santos ARF, Souza EM, Silva-Mann R and Ferreira RA (2010). Perfis enzimáticos de genótipos de Caesalpinia ferrea var. leyostachia e Cassia grandis. Flor. ambient. 17: 37-43.

Vasconcelos CF, Maranhão HM, Batista TM, Carneiro EM, et al. (2011). Hypoglycaemic activity and molecular mechanisms of Caesalpinia ferrea Martius bark extract on streptozotocin-induced diabetes in Wistar rats. $J$. Ethnopharmacol. 137: 1533-1541. 